\title{
Investor-State Dispute Settlement Reform at UNCITRAL: A Looming Constitutional Moment?
}

2017 Roll of Honors - Changes to the Masthead

Some constitutional moments, like the transformation of France's Third Estate into a National Assembly on 17 June 1789, come with a big blast and are recognizable as such almost immediately by its contemporaries. Others are quieter, more subtle; they creep in rather than explode, but are no less fundamental in transforming socio-institutional arrangements. The work of the United Nations Commission on International Trade Law (UNCITRAL) on 'InvestorState Dispute Settlement (ISDS) Reform', which started for good in late $2017,{ }^{1}$ may well be the beginning of such a constitutional moment in international economic governance.

While Working Group III, tasked to address ISDS reform, is for now still focused on the first two of its three-step mandate - problem-analysis and assessing the desirability of reform - it will most certainly reach the final stage of its mandate and 'develop any relevant solutions'. ${ }^{2}$ This is when a constitutional moment looms, in the argumentative showdown and decision on how to achieve systemic ISDS reform: whether through further institutionalization, for example by creating a permanent multilateral investment court, as supported by the European Union, or through more limited procedural reforms of investor-State arbitration, as championed by the United States. ${ }^{3}$ If consensus can be reached to create a permanent multilateral institution - in the form of

1 See UNCITRAL, 'Report of Working Group III (Investor-State Dispute Settlement Reform) on the Work of Its Thirty-Fourth Session (Vienna, 27 November-1 December 2017)' UN Doc No A/CN.9/930 (19 December 2017).

2 For the scope of the mandate, see United Nations, 'Report of the United Nations Commission on International Trade Law of its Fiftieth Session (3-21 July 2017)' Official Records of the General Assembly, Seventy-second Session, Supplement No 17, UN Doc No A/72/17 (2017) para 264. For an overview over the scope of issues that will likely be addressed as part of the problem analysis, see UNCITRAL, 'Possible Reform of Investor-State Dispute Settlement (ISDS) - Note by the Secretariat' UN Doc No A/CN.9/WG.III/WP.142 (18 September 2017) paras 20 et seq.

3 A third, minority position, supported above all by Brazil, would prefer a state-to-state system. 
an appeals body for investor-state arbitral awards or as a two-tiered investment court - it will bring about a watershed, a truly constitutional moment, in international economic governance comparable to the creation of the World Trade Organization (WTO) almost 25 years ago.

The creation of a permanent body could ensure the coherent and consistent application of international investment law, contribute to its further development, and help alleviate many of the other legitimacy concerns the present ISDS system has raised. The creation of such a body would be an appropriate way to address the 'constitutional challenge' the present ISDS system has posed for core constitutional principles common to many domestic legal systems, such as democracy, the rule of law, and human rights. ${ }^{4}$ That this is where the whole process is headed is underpinned both by the genesis of the UNCITRAL process, where the issue of further institutionalization loomed large, ${ }^{5}$ and the atmosphere in Vienna, which has been described as 'highly political' and 'polarized', 6 as is typical and appropriate on the eve of constitutional moments.

Moreover, the current UNCITRAL process has the potential of delivering a constitutional response in the form of further institutionalization of ISDS. It provides a deliberative and transparent platform that allows for the type of debates that should precede constitutional moments. Already with respect to the choice of forum, the process has avoided traps of earlier negotiations of

4 See Stephan W Schill, 'Reforming Investor-State Dispute Settlement: A (Comparative and International) Constitutional Law Framework' (2017) 20 JIEL 649, 652-657.

5 In fact, one of the driving forces in initiating the UNCITRAL process were prospects of developing the legal framework necessary for further institutionalization of ISDS. See UNCITRAL, 'Possible Future Work in the Field of Dispute Settlement: Reforms of InvestorState Dispute Settlement (ISDS) - Note by the Secretariat' UN Doc No A/CN.9/917 (20 April 2017) paras 29-32 and Gabrielle Kaufmann-Kohler and Michele Potestà, 'Can the Mauritius Convention Serve as a Model for the Reform of Investor-State Arbitration in Connection with the Introduction of a Permanent Investment Tribunal or an Appeal Mechanism? - Analysis and Roadmap' (3 June 2016) <www.uncitral.org/pdf/english/commissionsessions/unc/ unc-49/CIDS_Research_Paper_-_Can_the_Mauritius_Convention_serve_as_a_model.pdf> accessed 17 January 2018.

6 The start of the first UNCITRAL session on ISDS reform even saw the need for delegates to resort to a vote to break a deadlock over who was to chair the Working Group, possibly already driven by the looming issue of further institutionalization. For accounts of the Vienna session see Luke Eric Peterson, 'UNCITRAL Meetings on ISDS Reform Get Off to Bumpy Start, as Delegates Can't Come to Consensus on Who Should Chair Sensitive Process - Entailing a Rare Vote' (IAReporter, 9 December 2017); Anthea Roberts, 'UNCITRAL and ISDS Reform: Not Business as Usual' (EJIL:Talk!, 11 December 2017). 
multilateral investment rules, whether in the Organisation for Economic Cooperation and Development (OECD) in the 196os and 199os, or in the WTO early during the Doha Round. As part of the United Nations, UNCITRAL draws on universal membership and is less prone to being seen as biased towards economically powerful states. Moreover, possibly in order to prevent special-interest capture, the process has been entrusted to Working Group III, not Working Group II, which had addressed transparency in investor-State arbitration before and counted numerous arbitration practitioners among its delegates. The current process, by contrast, is markedly 'government-led', consensus-based and transparent; and any outcome will be subject to subsequent adoption by each State at their own choice. ${ }^{7}$ Structurally, the process therefore rests on much better foundations than any other attempt at creating multilateral investment rules and institutions before.

Certainly, the current process entails many risks. It could be stalemated if no consensus is reached or result in a watered-down or imbalanced system if consensus means either the lowest common denominator or overemphasis of state interests, without taking investor interests duly into account. Yet, these risks can be minimized through appropriate working methods and diplomatic finesse. Consensus-building can be supported, for example, by distilling constitutional principles common to UN members and translating them into concrete reform goals. ${ }^{8}$ Also, drawing on the reform discussion and proposals made in other international fora, including in the United Nations Conference on Trade and Development (UNCTAD), the OECD, and various regional organizations in Africa, Asia, and Latin America, as well as recent investment treaty practice and model treaties, can show areas of convergence.

Finally, the inclusion of all stakeholders, public and private, representing business and non-business interests, in the deliberative process can ensure balance and create results that will be broadly accepted by States, investors, and third parties alike. This inclusion could take place not only through observer status in the UNCITRAL process, but also, as is the case with the OECD, through advisory committees that group different stakeholder communities. This helps institutionalize exchange among stakeholders and integrate it better into the current deliberations of delegates. Moreover, one should not forget that the resolution of investment disputes, and the promotion of foreign investment connected with it, is in the common interests of both investors and States. States, in turn, increasingly have both offensive and defensive interests

7 See United Nations, Official Records of the General Assembly (n 2) para 264.

8 For this proposal see Schill (n 4) 657-661. 
and will be interested in finding a balance acceptable for both investors and States. Against this background, the lack of balance in outcome to the detriment of investors, which some fear, should not be over-dramatized. Conversely, with appropriate participation of non-business stakeholders in the reform process, the future design of ISDS should result in respecting their interests as well.

An important task for an inclusive process will also be to achieve constructive engagement of the international arbitration community. Many in this community oppose further institutionalization for a variety of reasons. Many consider the criticism of ISDS to be based on incorrect facts and politicized perceptions and oppose State intrusion into what they see as a generally wellworking system; others fear that their business model in international arbitration may suffer damage; and again others are concerned that changes to ISDS may spill over and interfere with the functioning of international commercial arbitration. These concerns should be taken seriously and addressed as part of the current process by seeking the active participation of the international arbitration community. After all, it makes sense to involve experts to understand the functioning of the present system and fathom options for reform, in particular when technical issues, such as third-party funding or best practices in case management, are concerned. Finally, it is important, in order to assuage concerns in the international arbitration community, to stress the limits of any outcome of the current process. Despite the excitement the creation of a permanent investment court would generate, it would affect neither international commercial arbitration, nor contract-based investor-state arbitration, and would only incrementally replace treaty-based investor-state arbitration. It would be a constitutional moment that still needs to prove itself in meeting the high expectations now placed upon it and only gradually replace the ancien régime of ISDS.

\section{Roll of Honors - Changes to the Masthead}

A peer-reviewed journal would be nothing without the gratuitous support of expert reviewers. Apart from members of the Editorial Board, whose institutional duty it is to contribute to the peer review process, the following colleagues have kindly agreed to accept requests for reviews for JWIT in 2017: Juan Pablo Bohoslavsky, Anna Joubin-Bret, Lorenzo Cotula, Meng Fang, Sotonye Frank, Abba Kolo, Nicolas Lamp, Chi 'Cliff' Manjiao, Anna Marhold, Makane Moïse Mbengue, Bryan Mercurio, Neha Mishra, James Nedumpara, Daniel Peat, Gonzalo Villalta Puig, Yannick Radi, Celine Tan, Valentina Vadi, 
Federica Violi, Tania Voon, and Jason W Yackee. Last but not least, I would like to thank Julie Maupin, Jorge E. Viñuales, and Heather Bray, who stepped down from their editorial positions, for their services.

Thank you all!

\section{Stephan W. Schill*}

* I wish to acknowledge support in writing this Editorial by the European Research Council Starting Grant on ‘Transnational Private-Public Arbitration as Global Regulatory Governance: Charting and Codifying the Lex Mercatoria Publica' (LexMercPub - Grant Agreement No 313355) carried out at the Amsterdam Center for International Law (ACIL). 